\title{
農の主体の二極化現象に見るオルタナティブな農村進化の可能性 \\ ベトナム紅河デルタ農村における「多様就業」と食と農に関する事例研究 \\ Possibility of Alternative Rural Development in Observation on Bipolarization of Farming Management Styles
}

A Case Study on "Pluriactivity" and Food and Agriculture in the Rural Area of the Red River Delta, Vietnam

\author{
井上 果子* \\ Kako INOUE* \\ (*宮崎大学地域資源創成学部) \\ (*Faculty of Regional Innovation, University of Miyazaki)
}

\section{I 問題意識}

\section{1 世界的に二極化する農の主体と食と農の関係性}

農業とフードシステムの産業化とグローバル化が世界 各地で進行している。そのような中, 農場の大規模化（あ るいは, 小規模農場の集約化) ・農業経営体の法人化, 農 産物の高付加価值化, さらに高度な技術の開発・採用な じを通じた農業の経済効率性向上への努力が進んでいる。 一方, 農を営む主体の動向をみると, 経済効率性を強化 する主体（法人化や経営規模を拡大寸る主体など）が出 現する流れの対極に, 小さな農を営み続ける主体の存在 がある。その農の主体の形態が二極化する傾向は, 世界 的に普遍的に見られると指摘されている ${ }^{1)}$ 。また, 進行 するグローバル化に反するように, 食と農を地域や顔の 見える関係性の中に取り戻そうとする潮流も世界各地で 確認されている。例えば, 欧米全体に広がる「地域支援 型農業 (CSA：Community Supported Agriculture)」な ど，食と農の信頼関係に基づくネットワークがますます 注目されるようになった。日本に目を向けると, 農林業 センサスによると, この 20 年間, 総農家数は 3.44 百万 戸（1995 年）から 2.16 百万戸（2015 年）と減少の一途 をたどっているが, 自給的農家数は一定数 (80万戸前後) を保っている ${ }^{2)}$ 。さらに, 生産者から近しい親類に譲渡 される縁故米とも呼ばれる無償譲渡米の存在について, 1980 年前後はコメ消費量全体の 5〜6\%だったものが 2005 年時点で $8 \%$ 程度を占めるようになるなど, 上昇傾 向にあるとの指摘もある ${ }^{3)}$ 。

\section{2 「小農」再評価とアジアの小農}

二極化の一極である小さな農をとらえる言葉について, 日本語では, 「小規模農業」「小農」「家族農業」, その主 体の英語による表現は， smallholders， peasants， farming families 等と多様で, 議論の文脈によって異な
る。国際連合（以下，「国連」）世界食糧保障委員会の HLPE (専門家ハイレベルパネル)による報告書 ${ }^{4)}$ は, smallholder agriculture は，世界各地で様々な定義が なされていると指摘している。また，同報において，農 地生産規模等による画一的な定義はなされるべきでない としつつ，それは，家族による，家族労働力を用いた農 であり，雇用された労働力を用いた大規模な利益追求型 の農業や土地なし労働者とは異なる, と解釈している。

本論で議論の対象としたいのは, 利益追求や資本蓄積 のために農業を営む農の主体 (以下,「農業経営体」注 1) と対極にある家族労働を中心に自らの食を生産・供給し, 農のある暮らしを実現する農の主体及びその農的生産活 動（以下，「小農」）である。小農の定義を巡る議論にお いては, その規模の大小や労働力の別（雇用労働か家族 労働か) など，さまざまな指標が提示されているが，本 論では農を営む主たる目的（すなわち，利益を追求する 農業か, 農村の人々の食や暮らしの充実を主たる目的と する農か）が異なる農の主体の出現と進行に関する二極 化に注目する注 2)。

小農が世界的に再評価される動きは, 2011 年の国連総 会において, 小農が持続可能な食料生産の基盤として世 界の食料安全保障確保と貧困撲滅に大きな役割を果たし ていると認識され，2014 年「国際家族農業年」が定めら れた他, 2017 年の国連総会で 2019 年から 2028 年までの 10 年を「家族農業の 10 年」としたことからもわかる。 世界の農民の約 $85 \%$ が，2ha 未満の農地を使用し，その 人数は 4 億 5 千万人（その 9 割近くがアジアの農民で, うち 1 億 9 千 3 百万人が中国, 1 千 7 百万人がインドネ シア, 1 千万人がベトナム) と推定されている ${ }^{4) 6) 。 ま た, ~}$ それらの国は，経済成長を遂げる新興国でもある。その 経済成長著しいアジアの国々において，暮らしを維持す るための農業が以前ほど重要ではなくなったにもかかわ らず，なぜ多くの人々は農を営み続けるのか。この問題 
関心を巡る議論において, Rigg らは零細農家の(1)経済的 優位性（特に稲作農家は家族経営体の方が, 競争力が高 い)，(2)（保護政策がとられるなどの）政治的優位性，(3) 農内外での多様な生計確保手段や就業機会に接する中で の生活戦略上の選択である可能性などに言及している ${ }^{6)}$ 上記(1)及び(2)で農を継続する農家は, 農業経営体と位置 づけられる。一方, 小農は, 暮らしを目的に農を営む主 体である。本論は, 小農を再評価する立場に立ち, 農村 に暮ら寸人々の生活上の戦略において如何に農が位置づ けられ, 継続されうるのか, という点 (3) に注目寸る。 具体的には, 多様な就業機会が存在する農村での暮らし に関連し, 人々の農の営みが農村社会に如何に組み込ま れうるか, といった視点をもって問題に接近したい。

\section{3 本論の目的}

市場経済化が急速に進み, 経済成長を遂げる国ベトナ ムにおいて，農の主体はどのような変化を遂げているの か。また, 食と農の関係において, 農村部の生産・消費 の実態はどのようになっているのか。本論で注目するの は, それら問題に直面寸る農村部の人々による生計手段 確保や食の生産に関わる動向, 及び食で他者とつながる 行為である。具体的には, (1)ベトナム紅河デル夕農村部 の個人, 世帯, 集落それぞれのレベルにおける農内・農 外就業の実態はどのようになっているのか, (2)農村部で 継続される「農」の実情及び小農が生産する食の消費は どうなっているのか, という問いについて, ベトナム紅 河デルタ農村部におけるフィールドワーク結果を示して いく。そのなかで, 農の主体の二極化現象, 特に農外就 業が可能となっても小農を継続する農村の人々の実態を 明らかにしていく。それらを通じ, 農業やフードシステ ムの産業化やグローバル化と対極に向からオルタナティ ブな農村進化の可能性や将来に向けた食と農の関係性に ついて示唆を得ることを本論の目的とする。

\section{II 調査方法及び分析の枠組み}

\section{1 ベトナム紅河デルタ地域における農の主体}

(1)ベトナム紅河デルタ地域の位置づけ

本論では, 世界で普遍的に見られる農の主体の二極化 現象について,急速に経済成長を遂げるアジアの中でも, 特に稠密な零細農家を抱え, 歴史的に多様な就業機会を 農村内部に確保していたことで知られるべトナム紅河デ ルタ地域を対象地としてとりあげる。べトナムは，1986 年のドイモイ改革を機に急速な経済成長を遂げている農 業大国である。ベトナム 2 大穀倉地帯の一つ, 紅河デル タの農村部は, 数世紀に渡り稠密な人口を抱えてきた特
徵をもち, 全農家の $90 \%$ 以上が 0.5 ha に満たない規模の

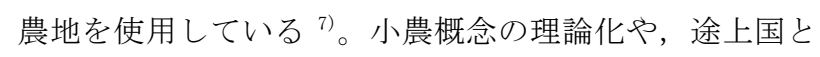
先進国の小さな農を再評価したPloeg は, 近代化以前の 小農は, 外部資源へのアクセスが限られた状況の中でサ ブシステンス (生存維持) のための自給的農業を行って いたのに対し，21 世紀の新しい小農については，(外部 資源へのアクセスが可能であっても）外部への依存を軽 減し内部における資源蓄積を拡大寸る自立的供給 (self-provisioning) へと変化していると指摘する ${ }^{8)}$ 。こ の指摘を紅河デルタ農村部に当てはめると, 確かに, 限 られた農地面積に対する稠密人口に関連し, その生存が 如何に可能となったのか, といった問いが以前の紅河デ ルタ地域研究上の関心の中心にあった。しかし, 現在に おいては, 都市部（ハノイ市中心部）に隣接する当該地 域において, アクセス可能となった多様な農外就業機会 を前に, 農業の重要性は薄れてきていると考えられる。 そのような特性をもつ紅河デルタ農村の事例研究によっ て, サブシステンスのための自給的農業, あるいは外部 依存軽減・内部資源蓄積のための自立的供給のどちらが, 小農が農を営み続ける目的に近いのか, 経済成長を遂げ るアジアの農村部における小農継続の実際について, 掘 り下げていくことが可能となる。

(2) 紅河デルタ地域の小農

肥沃な土壤を有寸大平野である紅河デルタには, 水田 稲作が紀元前から進展し, 村落の大部分が 13 世紀から 15 世紀にかけて灌溉移植型の稲作技術によって成立し たとされる ${ }^{9)}$ 。農地の使用については, 土地法改正 (1993 年)を通じ, 稠密な人口に対し, 平等な配分が行われた。 2006 年時点の紅河デル夕地域の平均水田面積は, $0.3 \mathrm{ha} /$ 世帯であるが注 3$)$, 数力所に農地が分散して使われるの が典型である。農家は, 生産活動の多角化や農外就業に よる所得向上を追求してきた特徴も持つ。農的生産活動 の多角化の代表例として挙げられるのはVAC システムと よばれるモデルである。VAC とは, V=Vuong(庭), A=ao(養 魚池), C= cuong (家畜小屋) の頭文字で, 果樹, 野菜栽培, 畜産，養殖を同時に行う複合的な生産活動を行うもので ある。農外就業については, 多様な伝統産業が農業の歴 史とともに展開してきた特徴をもつ。農家が使用する農 地は小規模で, 農地での生産活動以外に費や寸ことがで きる余剩労働力が豊富にあり, その労働力を農村内部で 活か寸職住一体型の手工業が発達した。

(3)紅河デルタ地域の農業経営体

紅河デルタ地域の小農の対極をなす農業経営体につ いては, 対象地の人々が「チャンチャイ(trang tra $i) 」$ と呼ぶ経営体の出現や進展を確認することができる。チ ヤンチャイは, 民間主体の比較的大規模な農林水産経営 
を指し, 2000 年ベトナム政府決議で公式に推奨された農 場経営形態である。その政府認可基準については, 2003 年に緩和され, 農場数が増加したが, 2011 年に基準が引 き上げられた。地域や生産される農作物等によっても基 準は異なり, 紅河デルタにおけるチャンチャイは, メコ ンデルタ地域の大規模農場経営との比較において小規模 で, 統計上, 経営体数は 2000 年以降急増している。また, 2006 年のデータでチャンチャイ数 3,511 の 7 割相当が畜 産といった特徵を持つ ${ }^{10)}$ 。研究対象地では, 小農よりも 比較的規模の大きい農場でVAC システムに沿った農場経 営を行う主体のことがチャンチャイと呼ばれており，そ の規模は必ずしも 2011 年の政府認可基準を満たすもの ではないが，利益を得ることができる営農形態として小 農とは区別して認識されている。

\section{2 調査対象及び調査方法}

調査対象地は, 紅河デルタ地域でも最も広い農地面積 を有す旧ハタイ省（2008 年にハノイ直轄市に合併）のチ ユオンミー郡及びミードゥック郡に位置する 3 村 5 集落 である。本対象地は, 異なる営農体制をもつ 3 村 (集落自 治が機能する A 村, 農業協同組合の管理が強い B 村, 他 からの関与が薄く個別世帯が自立的に農業を営むC 村) を対象に行ったアクションリサーチ事業(稲作技術移転・ 高付加価值販売支援事業) ${ }^{11)}$ の 3 集落に, 隣接する事業 対象外の 2 集落を加えたもので, 八ノイ市中心部からバ イクや車で片道約 1.5 ～時間かかる場所にある。

対象地におけるフィールドワークは, 2009 年からイン タビュー調査や参与観察等を継続しているものであるが, 本論の調査結果は, 主に(1)2014 年 11 月下旬から 2015 年 1 月にかけて行った世帯構成員の就業等に関する調査票 調查（調查 1.)，(2)2015 年 1 月， 3 月， 6 月，2016 年 9 月, 2017 年 9 月に実施した集落内農外就業グループのリ ーダーに対するインタビュー調査（調査 2.), (3)2017 年 9 月に実施した農と食のネットワークに関する農家 5 世 帯へのインタビュー調査（調査 3. ）に基づく。また, (4) 2012 年 2 月に実施した調査票調查結果 (調査 4. ), 及び (5) 2018 年 8 月に対象地から入手した農業経営体に関する データ（調査 5. ）も提示する注 ${ }^{4}$ 。調査 1 . については, 各集落を調査員 3〜4 名/集落が訪問し, 集会場に集ま った住民や集落居住地の全住居訪問で対面できた住民に 対する他記式面接調査法で実施した。対象地及び調査 1 . 概要を表 1 にまとめる。対象地の世帯数 2,425 のうち, 合計 800 世帯（全体の $33 \%$ ） から回答を得た。また, 世 帯の構成員の属性（生年, 性別, 就業形態, 在住地）に 対する有効回答数は全体で 3,066 であった。調査 1 . の主 な調査項目は，表 2 の通りである。
表 1 農村部調査対象地及び調査 1 .の概要

Table 1 Profile of study areas

\begin{tabular}{|c|c|c|c|c|c|}
\hline 行政村名 & \multicolumn{2}{|c|}{$\mathrm{A}$ 村 } & \multicolumn{2}{|c|}{ B 村 } & $\mathrm{C}$ 村 \\
\hline 営農主導主体 & \multicolumn{2}{|c|}{ 集落 } & \multicolumn{2}{|c|}{ 農協 } & 農家 \\
\hline 集落名 & a1 集落 & a2 集落 & b1 集落 & b2 集落 & c 集落 \\
\hline 事業関与の有無 & なし & 有 & 有 & なし & 有 \\
\hline 事業内容注 & （普及） & 販・技 & (販) 技 & - & 技 \\
\hline 総面積 (ha) & 89 & 45 & 175 & 155 & 150 \\
\hline 居住地面積 (ha) & 16 & 10 & 72 & 72 & 22 \\
\hline 世帯数 (世帯) & 570 & 202 & 623 & 460 & 570 \\
\hline 人口（人） & 2,300 & 745 & 2,150 & 1,960 & 2,021 \\
\hline 回収（世帯） & 183 & 153 & 170 & 119 & 175 \\
\hline 有効回答数（人） & 738 & 592 & 644 & 434 & 658 \\
\hline
\end{tabular}

注:「事業内容」について, 差別化販売活動「販」, 技術移転活 動「技」, 一時期のみ販売が実現し, 調査時は同活動がなかった b1 については「(販)」, 事業完了後 a 2 からの普及で一部が販売 活動を行っているa1について「(普及)」と表現した。

表 2 調査票調查項目

Table 2 Items of questionnaire survey

\begin{tabular}{|c|c|}
\hline & "主な質問項目 (有効回答数 : $n$, 無回答・非該当 : NA） \\
\hline $\begin{array}{l}\text { 世帯に } \\
\text { つてて }\end{array}$ & $\begin{array}{l}\cdot \text { 世帯構成員数 } \quad(n=800, \mathrm{NA}=0) \\
\cdot \text { 世带内における稼ぎ手の人数 } \quad(n=792, \quad \mathrm{NA}=8) \\
\cdot \text { 小農から得られる月収 }(n=459, \quad \mathrm{NA}=341) \\
\cdot \text { 私営農場経営から得られる月収 }(n=36, \quad \mathrm{NA}=764) \\
\cdot \text { 農外活動から得られる月収 }(n=600, \quad \mathrm{NA}=200)\end{array}$ \\
\hline $\begin{array}{l}\text { 世帯構 } \\
\text { 成員に } \\
\text { つて }\end{array}$ & $\begin{array}{l}\text { - 誕生年 }(n=3,066, \quad \mathrm{NA}=0) \\
\text { - 性別 }(n=3,062, \mathrm{NA}=4) \\
\text { - 従事している経済活動, 職業 / 身分 } \quad(n=3,054, \mathrm{NA}=12) \\
\text { - 同居の別 • 居住地 }(n=3,065, \quad \mathrm{NA}=1)\end{array}$ \\
\hline
\end{tabular}

\section{3 分析の枠組み}

農村部における多様な就業機会は, アジアに限らず, 世界的にみられるものであった。例えば，複数の就業機 会があったことは，産業革命以前の $\mathrm{EU}$ 諸国においても 見られ, その多様就業 (pluriactivity) について, 近年, 再興しているとの見方が指摘されている ${ }^{12)}$ 。ヨーロッパ では, 離農の経過について兼業・専業農家論とは異なる 多様就業という概念が形成され, 農村部での多様就業機 会の創出を推進する政策が導入されている。その概念形 成の過程には, 個人, 世帯, 地域における多様産業化= 農村社会的分業の多様性の範囲と段階があった。それは, 重層的構造下で行われる農的生産活動と他の経済活動と の多様な結合形態ともみることができる ${ }^{13)}$ 。本論では, その多様就業の概念を意識しつつ農の主体について, 個 人，世帯，地域共同体（集落）それぞれの段階で就業の 実態をとらえる。また, 農村に暮らす人々が営む小農の 実態を捉えるために, コメ生産に限らず，食卓に上がる 食材として野菜, 果物, 肉類の生産者及び消費者の側面 について聞きとった調査結果を示す。

III 調査結果

1 対象地人口の年齢構成及び移動状況 
調査 1. 結果について, 世帯構成員の年齢と性別につい て, 図 1 に示す。最も多い人口を持つ年齢層は 20 代から 30 代である。さらに, 年齢構成について, ベトナム全体 人口と対象地人口の比較を図 2 に示寸。対象農村部はべ トナム全体との比較で若年層は比較的少なく, 高齢層は 多いものの 25-54 歳の生産年齢層は同程度となっている。 集落内人口の移動の状況についてまとめたものが表 3 である。全体の $11 \%$ が出身集落から離れ, 他出している 状況にあるが，そのほとんどが八ノイ市中心部やベトナ ム北部に集中している。また, 他出している人口につい ては, 他出者 332 人のうちの $57.2 \%$ に相当する 190 人が 25-54 歳層で最も多く, 次いで 130 人（全体の $39.2 \%$ ) が 15-24 歳層となっている。

\section{2 就業形態}

対象地の世帯構成員が従事する経済活動について調 査 1 .の結果及び集落における農外就業に関する関係ア クターにインタビューした調査 2 . の結果を本節で示す。 (1) 個人レベル

世帯構成員それぞれについて，所得源を把握するため に, 次のどの活動を行うか（又はどの立場にあるか）を 調查した注 5) : (1)農的生産活動（小農）, (2)農場経営（農 業経営体), (3)手工芸, (4)建設労働, (5)工場労働, (6)行政 (公務員), (7)販売業, 8) その他活動, (9)公的支援(戦傷者・ 障碍者手当て, 年金など), (10)子供・学生。各個人が(1)〜 8の活動のいくつに従事しているか集計し, 年齢で整理 したものが, 図 3 である。ここからは, 生産年齢にあた る 25-64 歳層に 2 種以上の形態に就業している個人が存 在することがわかる。農的生産活動と組み合わせて従事 する就業の形態を表 4 に示す。農的生産活動を行う個人 (全体で 1,353 人: 子供・学生を除く有効回答数 2,155 人 の $62.8 \%$ に相当)のうち公的支援受給者を含め 581 人が 農外に所得源を確保している。男性は建設労働, 女性は 手工芸や販売業と組み合わせるケースが多くみられる。

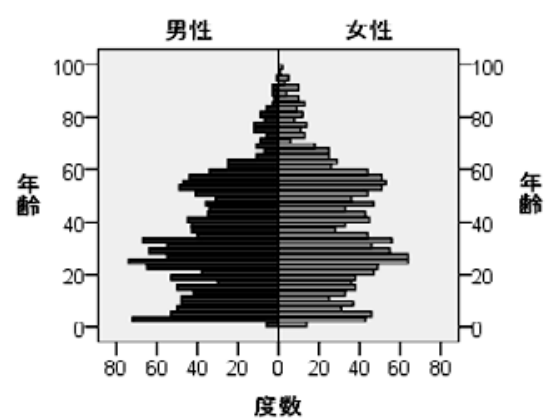

図 1 対象地（全体）の人ロピラミッド（2015 年）

Fig. 1 Population pyramid of the target area (2015) 注 : $n=3,062$. 平均值 35.27 (男性 32.77, 女性 37.81)。

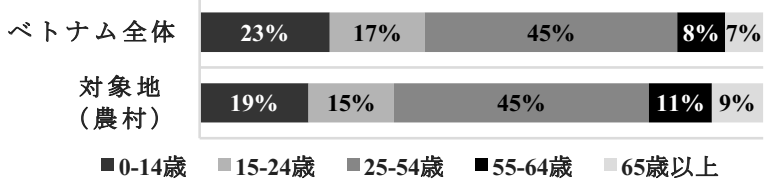

図 2 対象地・ベトナムの年齢構造比較（2015 年）

Fig. 2 Comparison of age structure: target area and country (2015) 注 : 全体人口は, United Nation (2017) World Population Prospects. The 2017 Revision, DVD Edition.より算出。

表 3 対象地人口の移動状況 (人)

Table 3 Population movement of the target area (person)

\begin{tabular}{|c|c|c|c|c|c|c|c|c|}
\hline \multicolumn{2}{|r|}{ 集落名 } & a 1 & a2 & b1 & b2 & $\mathrm{c}$ & 合計 & $\%$ \\
\hline \multicolumn{2}{|r|}{ 集落内居住 } & 670 & 546 & 558 & 397 & 561 & 2,732 & $89 \%$ \\
\hline \multirow{6}{*}{$\begin{array}{l}\text { 他 } \\
\text { 出 }\end{array}$} & $\begin{array}{l}\text { 八ノイ市 } \\
\text { 中心部 }\end{array}$ & 45 & 34 & 63 & 29 & 74 & 245 & $8 \%$ \\
\hline & $\begin{array}{l}\text { ベトナム北部 } \\
(\text { ハノイ市除く) }\end{array}$ & 11 & 8 & 14 & 5 & 11 & 49 & $2 \%$ \\
\hline & ベトナム中部 & 3 & 0 & 0 & 0 & 1 & 4 & $0 \%$ \\
\hline & ベトナム南部 & 8 & 3 & 6 & 3 & 8 & 28 & $1 \%$ \\
\hline & 海外 & 1 & 0 & 1 & 0 & 0 & 2 & $0 \%$ \\
\hline & その他 & 0 & 0 & 2 & 0 & 3 & 5 & $0 \%$ \\
\hline
\end{tabular}

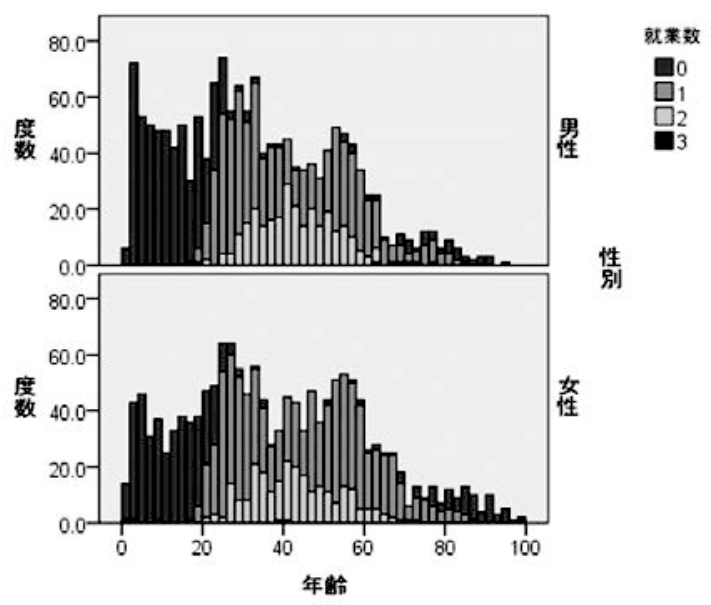

図 3 個人が従事する就業の数

Fig. 3 Number of individual income-generation activities 注 : 就業なし：1,070，1 就業:1,456，2 就業:525，3 就業: 3 。

表 4 農的生産活動とともに従事する形態（人） Table 4 Type of "pluriactivity" matched with small farming (person)

\begin{tabular}{c|c|c|c|c|c|c|c|c}
\hline \hline & 手工芸 & 建設 & 工場 & 行政 & 販売 & その他 & $\begin{array}{c}\text { 公的 } \\
\text { 支援 }\end{array}$ & 合計 \\
\hline 男性 & 11 & 112 & 14 & 11 & 30 & 86 & 38 & 302 \\
\hline 女性 & 73 & 24 & 22 & 19 & 68 & 42 & 31 & 279 \\
\hline 合計 & 84 & 136 & 36 & 30 & 98 & 128 & 69 & 581 \\
\hline$\%$ & $14 \%$ & $23 \%$ & $6 \%$ & $5 \%$ & $17 \%$ & $22 \%$ & $12 \%$ & $100 \%$ \\
\hline
\end{tabular}

(2) 世帯レベル

回答のあった 800 世帯のうち, 農的生産活動を行う世 帯数は 711, 農場経営世帯数は 38 で, 合計 749 世帯（全 体の 93\%）が農を営んでいる。また，世帯内で農を営む 
構成員数については，世帯内の 1〜2 名で農業に従事し ているケースがほとんどである（表 5 )。次に，農的生産 活動, 農場経営, 農外活動から得られる世帯あたり収入 は, 表 6 の通りである。調査 1 .を実施した際, 特に農外 収入に関して少なく回答する，あるいは回答しないケー スや非公式な経済活動に関しては回答を得にくいことが あったため, 本結果の信頼性に留意が必要である。また, 農場経営からの収入のばらつきが大きいことにも留意す べきである。それらを踏まえても，世帯収入を確認する と, 農外就業と農場経営の収入は, 農的生産活動からの 収入を大きく上回るレベルにある。小農が獲得できる農 内収入は極めて低く, 生計の足しになっても, それ単独 では生活を成り立たせることが困難であることが推測で きる。また, 農場経営世帯は, 農外就業と農的生産を両 立させる世帯よりも多くの農外収入を得ている。

なお，対象地における農場経営は，養豚のための施設 や養殖のための溜池などを含むVACのための（居住地と 離れた）立地条件やそのための農地規模の確保が必要と され, 分散型零細農地で稲作を行う小農とは区別して認 識されている。調査 5. では, 各集落のリーダーに, どの ような主体が「チャンチャイ」と呼ばれているのか自由 記述方式で尋被たところ, 全回答に, (1)居住区から離れ た比較的広い農地を使用し, (2)VAC モデルに沿っている こと, が共通してみられた注 ${ }^{6)}$ 。さらに, 集落 $\mathrm{a} 2, \mathrm{~b} 1, \mathrm{~b} 2$ のリーダーから得られた回答には, 長期的発展のための 経営戦略や投資が必要とされるとの認識がみられた。

表 5 農を営む家族内構成員数（世帯数）

Table 5 Number of family member to practice farming (No. of $\mathrm{HH}$ )

\begin{tabular}{c|r|r}
\hline \hline 農を営む世帯構成員数 & 農的生産 & \multicolumn{2}{|}{ 農場経営 } \\
\hline 1 人 & 195 & 7 \\
\hline 2 人 & 419 & 36 \\
\hline 3 人 & 73 & 2 \\
\hline 4 人 & 19 & 0 \\
\hline 5 人 & 5 & 38 \\
\hline 合計 & 711 & \\
\hline
\end{tabular}

表 6 世帯あたり収入（2014 年）（VND/月）

Table 6 Household income in 2014 (VND/month)

\begin{tabular}{|c|c|c|c|c|}
\hline & & 農的生産 & 農場経営 & 農外のみ \\
\hline \multirow{4}{*}{$\begin{array}{l}\text { 農 } \\
\text { 内 } \\
\text { 収 } \\
\text { 入 }\end{array}$} & 有効回答数 & 454 & 38 & - \\
\hline & 平均（VND/月） & 788,430 & $5,172,895$ & - \\
\hline & 中央值（VND/月） & 572,200 & $3,230,000$ & - \\
\hline & 標準偏差 (VND/月) & 663,880 & $6,678,451$ & - \\
\hline \multirow{4}{*}{$\begin{array}{l}\text { 農 } \\
\text { 外 } \\
\text { 収 } \\
\text { 入 }\end{array}$} & 有効回答数 & 538 & 22 & 40 \\
\hline & 平均（VND/月） & $4,896,422$ & $7,480,909$ & $7,106,250$ \\
\hline & 中央值（VND/月） & $4,107,027$ & $5,000,000$ & $5,500,000$ \\
\hline & 標準偏差 (VND/月) & $3,397,554$ & $7,688,165$ & $4,524,098$ \\
\hline
\end{tabular}

注 : 同一世帯内に農場経営と農的生産活動のそれぞれの立場で 農を営む構成員がいる 2 世帯について, 農場経営体として計上 し, 当該世帯の農内収入は農的生産分と農場経営分を合算した。
対象地における 1990 年代以降の農場経営世帯数の増 減推移を確認したところ, 2003 年以降に 2011 年以前に 特に養豚を含む農場経営世帯の出現が目立つ（特に 2004 年から 2008 年にかけて 25 農場が出現し, 近年は 2017 年 に 5 つの農場経営体が出現している)。また, 調査 5 .に おいて対象地に存在する合計 50 の農場経営状況を把握 した。そのうち，2008 年よりも前に運営が開始されてい た 32 の農場経営体について, 10 年前との比較において, 経営農場面積及び収入の推移を確認したところ平均農場 面積は $6,282 \mathrm{~m}^{2}$ から $6,082 \mathrm{~m}^{2}$ と微減しているものの（但 し, 小農が使用する世帯あたり水田面積の約 2 倍に相当), 1 農場経営世帯あたりの平均年間収益は 52 百万ドン （2008 年）から 114 百万ドン（2018 年）へと増加してい る。ここからは, 対象地の農業経営体について, 紅河デ ルタ農村の稠密人口と利用可能な農地面積との関係にお いて, 農地の拡大は困難でありながらも, 農業経営から の収入が増加している実態を確認できる。

(3) 集落レベル

集落レベルでの就業の実態を把握する上で, 農の主体 の現状と農外就業の動向について確認する。まず，農場 経営世帯数は, 農を営む全世帯のうちの $5 \%$ 程度である が，集落別では a 2 のみ $13.3 \%$ と高い割合を示している (表 7 )。集落 a 2 は，農作物の差別化販売や技術移転支 援が最も継続・定着した特性をもつ集落である。農場経 営の農産物のタイプを見ると, 有効回答 35 のうち, 26 世 帯が畜産, 17 世帯が稲作, 7 世帯が水産, 3 世帯が野菜 栽培, 3 世帯がその他の農業に従事し，17 世帯が（複数 タイプの農産物を生産する）多角経営体である。

次に, 農外就業について表 8 によめた。農外就労の 実態を調查 2. で質的に確認すると，伝統的地場産業にお ける就業機会と近代的に創出された就業機会が集落内で 混在していることがわかった。具体的には，集落内にお ける「手工芸」の就業機会について, a1 及び a 2 におい ては, 伝統的地場産業である竹・筄細工を行う集団と, a2 では外資企業輸出商品の下請け製作をする集団, 集落 c では, 主に中国に輸出される木工品の製造工程の一部 を下請けしている集団が集落内で組織されていた。いず れの集落においても集落内で作業集団が組織され, 就業 機会が共有されている状況にあった。集落 a2 ではこの 10 年程度の期間をかけて, 集落 c では, 近年において農 外就業の組織化が進展している。具体的には, 集落 $\mathrm{a} 2 に$ おいて, 建築・リフォーム（天板貼り付け）作業に特化 したサービスを行う集団が集落内に 8 つ, 近隣集落に 2 つ組織され, 各集団は 4 5 人から構成されている。この 就業機会は 2001 年頃ベトナム南部から U ターンした人 物が集落内で作業集団を組織し，仕事をグループで始め 
たことから始まった。仕事量が増えると集落内で集団を 増やして対応し, 現在の合計 10 集団にまで発展した。ま た，10 集団すべてにおいて親せき関係にある人々が各集 団のリーダーを務めている。但し, 対象地集落は, 父系 集団から組織される特徵があり, 集落 $\mathrm{a} 2$ すべての人口 は，7 つの父系家族のいずれかに属し，ほとんどが親戚 関係にある。作業集団のリーダーが能力に応じて報酬を 分配する役割を担い，月毎に報酬が支払われる。このよ うに, 例えば建設労働を行うにしても集落内に複数の作 業集団が重層的に組織されている。

集落 c では，木工製品の作業集団が 1 つ組織されてい る。集落 c から車で 1 時間ほど離れた場所に伝統的に木 工業を集落全体で営む集落 Nがあり, その集落から材料 などを預かり, 集落 $\mathrm{c}$ が一部工程を作って集落 $\mathrm{N}$ に納品 する体制がとられている。集落 c 内で木工製品の作業に 参加者の人数について 2015 年 1 月から 2017 年 9 月にか けて，いずれも 40〜50 世帯程度との回答であった。ま た, 農繁期か農閉期かで参加者数が変動し, 集落内の人々 の生活リズムに応じて就業機会が共有されていた。

表 7 集落内における農場経営主体の出現状況

Table 7 Emergence of large-scale farming household within a village

\begin{tabular}{c|r|r|r}
\hline \hline & 農的生産 (世帯) & 農場経営 (世帯) & $\begin{array}{c}\text { 全体に占める } \\
\text { 農場経営の割合 }\end{array}$ \\
\hline a1 & 157 & 3 & $1.9 \%$ \\
\hline a2 & 124 & 19 & $13.3 \%$ \\
\hline b1 & 164 & 3 & $1.8 \%$ \\
\hline b2 & 104 & 4 & $3.7 \%$ \\
\hline c & 162 & 9 & $5.3 \%$ \\
\hline 合計 & 711 & 38 & $5.1 \%$ \\
\hline
\end{tabular}

表 8 農外就業の状況（人）

Table 8 Non-farming activities (person)

\begin{tabular}{c|r|r|r|r|r|r|r}
\hline \hline & 手工芸 & \multicolumn{1}{|c|}{ 建設 } & \multicolumn{1}{c|}{ 工場 } & \multicolumn{1}{c|}{ 行政 } & 販売 & その他 & 合計 \\
\hline $\mathrm{a} 1$ & 22 & 49 & 63 & 21 & 40 & 79 & 274 \\
\hline $\mathrm{a} 2$ & 42 & 38 & 38 & 11 & 38 & 82 & 249 \\
\hline $\mathrm{b} 1$ & 5 & 43 & 41 & 40 & 25 & 74 & 228 \\
\hline $\mathrm{b} 2$ & 16 & 23 & 23 & 11 & 9 & 36 & 118 \\
\hline $\mathrm{c}$ & 14 & 36 & 43 & 24 & 37 & 65 & 219 \\
\hline 合計 & 99 & 189 & 208 & 107 & 149 & 336 & 1,088 \\
\hline
\end{tabular}

\section{3 生産と消費の実態}

多様な農外就業機会が農村内で確認されたにもかかわ らず，集落内の多く（全世帯の 93\%）が農を営み続ける 実態を前節で確認した。さらに, 対象地におけるフィー ルドワークでは, 各世帯の家屋敷地内外の様々な土地の 隙間を使用し, 多様な農作物が栽培されていることを観 察した。栽培・収穫された農産物がごこでどのように消 費されるのか調査 3.で聞きとった内容を表 9 に示す。対 象者(1)〜 (3)については, 使用権をもつ水田で稲作を行う 対象地で典型的な小農である。加えて, C 村については,
農外就業において責任ある立場を担う (4)農業技術普及上 の指導者, 及び(5)農外就業グループ・リーダーからも現 状について聞きとった。対象地を訪問・観察した際，敷 地内にはバナナや柑橘系の果樹と多品目の野菜が庭や露 地に栽培され, 鶏など家畜が飼育されていたがインタビ ユー結果からもその様子がわかる。特に野菜や果物は, 使用権を有す土地・農地に栽培されるとは限らず，あら ゆる隙閒が栽培機会ととらえられ，使用権の有無に関わ らず栽培に使われている。消費については，小農の親族 内で農作物が共有・食されている実態を把握できる。ま た, 生産した農作物は, 他出した子息の家族にも供給さ れ, 集落を超えた食の親戚縁者供給ネットワークも確認 できる。さらに，小農を担う主体自身の就業上の調整の 仕方として, 農外活動が多忙となった C 村 $\mathrm{c}$ 集落の 45 歳 女性や 39 歳女性のケースでは, 水田面積を少なくして 自家消費に必要な分の夕稲作を続ける, あるいは, 稲作 を断念し, 近隣農家からコメを調達しつつも野菜等の栽 培は自給目的で続けていることが確認できる。

さらに, 農外就業と小農が両立される場合の生計につ いて, 農村の人々がどのような認識でいるのか,「農内収 入と農外収入がある場合, 世帯収入について生活を営む 上で, 如何に評価するか」調査 4. で尋ねた質問について, 選択肢「(1)十分, (2)よくも悪くもない, (3)不十分, (4)農 外収入がない (単一回答)」のうち, (1) $13 \%$, (2)63\%, (3) $12 \%$ ，(4) $5 \%$ ，無回答 7\%との回答を得た。ここから，(1) と(2)の合計の $76 \%$ の人がある程度は生活できると認 識していることがわかる。また，農業継続理由について 尋ねた質問（複数回答）について, 最も多かったのは, 自給のため $(n=266$ のうちの $92 \%)$ であり，農作物販売 による生計上の収入確保のためとの回答は $36 \%$, 農地利 用のためは $18 \%$, 無回答 4\%であった。

\section{IV 考察及び結論}

オルタナティブな農村進化の可能性を考える上で注 目したいのは，現代において農外就業機会の共有という 形で発現されている農村部に残る共同性や，零細で農外 就業に就いていても生産を続ける大多数の小農とその 人々が自立的に供給する食の存在である。共同性によっ て農村部に暮らす人々の生計が確保され, 小農は, (たと え農外活動が多忙でも）農を継続し，子息・親せきにも 食を供給する。その小農の行為は,「サブシステンス（生 存維持）のための自給的農業」では説明できず，食を自 立的に供給できる状況を自らの意思で維持しているよう に見える。例えば, 食の安全問題が深刻化する外部環境 に身を曝し, 商品化された食のコストが上がっても, 自 
らの手で安全な食を確保できる意味において，小農は， コストをかけずに暮らしを充実させうる確実な存在と評 価できる。また，農村内で重層的に組み込まれている多 様就業と農の実態からは, 農村部の個人, 世帯, 地域の 社会的分業の構造が現代社会経済に適応しつつ機能して いることを把握でき，そのことは，将来起こりうる変化 にも適応できる農村に残る屈強な機能となる可能性を期 待させるものでもある。

本論では, 農の主体の二極化現象に関連し, ベトナム 紅河デルタ地域の事例について，個人，世帯，集落それ ぞれのレベルにおける農内・農外就業の実態, 及び対象 地で生産される食と農の実態について調査結果を示した。 結論として，まず，二極化現象について，人口密度の高 い紅河デル夕農村部において, (農地規模拡大はみられな いものの）近年における農業経営体数の増加やそれら主 体の農業経営収入増加が確認された一方で, 自立的供給 を主目的に小農を継続する大多数（全体の 93\%の世帯） の存在を確認した。個人, 世帯, 集落レベルの就業の実 態からは，個人は農外就業と農的生産活動を両立させう ること, 農を営む世帯は小農と農業経営体の収入に大き な差があり，小農のみでは生計が成り立たなくとも農外 就業との組み合わせで生計が成り立ちうること，集落レ
ベルでは，複数の農外就業機会が集落内で共有されてい る実態と集落内の一部の世帯が農業経営体として台頭し, 農外就業からの収入と同程度の収入を得ていることを把 握した。また，農村部で継続される「農」の実情と食の 消費先については, 自家及び親族内で農作物が消費され, 他出した子息の家族にも供給されるなど，集落を超えた 食の親戚縁者供給ネットワークがある実態も確認した。

産業化やグローバル化が進む中で小農が存続する意 味，さらには，外部に依存することなく人々が食を自立 的に供給し続けることができる農村社会の構造や機能に 注目し，さらにグローバルな文脈で農村進化の可能性に 関する議論を重ねることを今後の課題としたい。

\section{謝辞}

調查活動において対象地及びベトナム国家農業大学協力者の 皆さまに多大なるご支援を頂きましたこと,ここに付記します。

\section{注}

注 1）「農業経営体」概念については, 企業形態論や家族農業経 営の考え方，あるいは，「農業経営体」と「農家」の農林業 センサス上の定義が整理されているが，本論においては, それらとは関係なく，利益を追求する目的で農業を経営す

表 9 農的生産活動と消費に関する聞き取り調査結果

Table 9 Interview results on small farming production and food consumption

\begin{tabular}{|c|c|c|c|c|c|c|}
\hline & & 消費者・生産者 & コメ & 野菜 & 果物 & 肉類 \\
\hline \multirow{2}{*}{$\begin{array}{l}\text { (1) } \\
65 \text { 歳女性 } \\
\text { (A 村 a } 2 \\
\text { 集落) }\end{array}$} & $\begin{array}{l}\text { 消 } \\
\text { 費 }\end{array}$ & $\begin{array}{l}\text { 自家消費者数: } 3 \text { 人 } \\
\text { 八ノイ市の子供と農 } \\
\text { 産物を供給 }\end{array}$ & $\begin{array}{l}\text { 収穫したコメの } 50 \% \text { を } \\
\text { 家族内と親せきで消費。 } \\
50 \% \text { 販売。 }\end{array}$ & $\begin{array}{l}\text { ほとんどを家庭内で消 } \\
\text { 費, わずかな量を親せき } \\
\text { に分け, 不足分を購入。 }\end{array}$ & $\begin{array}{l}\text { マンゴーを自家消費用 } \\
\text { に栽培・消費。少し他品 } \\
\text { 目を購入。 }\end{array}$ & $\begin{array}{l}\text { 鶏を自家消費及び } \\
\text { 親せき内で消費。 }\end{array}$ \\
\hline & $\begin{array}{l}\text { 生 } \\
\text { 産 }\end{array}$ & $\begin{array}{l}\text { 小農従事者数：1 人 } \\
\text { (回答者) }\end{array}$ & $\begin{array}{l}\text { 使用権のある水田で栽 } \\
\text { 培 }\end{array}$ & $\begin{array}{l}\begin{array}{l}\text { 使用権のない空き地で } \\
\text { 栽培 }\end{array} \\
\end{array}$ & $\begin{array}{l}\begin{array}{l}\text { 使用権のない空き地で } \\
\text { 栽培 }\end{array} \\
\end{array}$ & $\begin{array}{l}\text { 使用権を持つ土地 } \\
\text { で飼育 }\end{array}$ \\
\hline \multirow{2}{*}{$\begin{array}{l}\text { (2) } \\
34 \text { 歳女性 } \\
\text { (B 村 b1 } \\
\text { 集落) }\end{array}$} & $\begin{array}{l}\text { 消 } \\
\text { 費 }\end{array}$ & $\begin{array}{l}\text { 自家消費者数: } 4 \text { 人 } \\
\text { 近隣に住む親兄弟及 } \\
\text { び他集落に住む実母 } \\
\text { に農産物を供給 }\end{array}$ & $\begin{array}{l}50 \% \text { を家族内で消費。残 } \\
\text { り } 50 \% \text { 販売。 }\end{array}$ & $\begin{array}{l}\text { 約 } 70 \% \text { を自家消費, } \\
30 \% \text { 親兄弟と分ける。 }\end{array}$ & $\begin{array}{l}5 \text { 種以上の果物をすべ } \\
\text { て自家消費用に栽培。 }\end{array}$ & $\begin{array}{l}\text { 鶏を自家消費（75\% } \\
\text { 程度）及び親兄弟 } \\
\text { (25\%程度) で消費。 }\end{array}$ \\
\hline & $\begin{array}{l}\text { 生 } \\
\text { 産 }\end{array}$ & $\begin{array}{l}\text { 小農従事者数：2 人 } \\
\text { (回答者と夫) }\end{array}$ & $\begin{array}{l}\text { 使用権のある水田で栽 } \\
\text { 培。 }\end{array}$ & $\begin{array}{l}\text { 家屋敷地周辺の空き地 } \\
\text { で栽培。 }\end{array}$ & 家屋敷地内 (庭) で栽培。 & $\begin{array}{l}\text { 家屋敷地内（庭）で } \\
\text { 飼育。 }\end{array}$ \\
\hline \multirow{2}{*}{$\begin{array}{l}\text { (3) } \\
59 \text { 歳女性 } \\
\text { (C 村 c } \\
\text { 集落) }\end{array}$} & $\begin{array}{l}\text { 消 } \\
\text { 費 }\end{array}$ & $\begin{array}{c}\text { 自家消費者数 : } 2 \text { 人 } \\
\text { ハノイ市に住む息子 } \\
\text { (2人) にコメ供給 }\end{array}$ & $\begin{array}{l}20 \%(240 \mathrm{~kg}) \text { を家庭内, } \\
80 \%(1,000 \mathrm{~kg}) \text { を八) } \\
\text { イ市の息子 } 2 \text { 人の家族 } \\
\text { で消費。 }\end{array}$ & $\begin{array}{l}\text { 自家消費する野菜の半 } \\
\text { 分程度を自給, 残り半分 } \\
\text { を購入。 }\end{array}$ & 自家消費用にのみ栽培。 & $\begin{array}{l}\text { 鶏を自家消費用に } \\
\text { 飼育 }(30 \text { 羽 } / \text { 年程 } \\
\text { 度)。 }\end{array}$ \\
\hline & $\begin{array}{l}\text { 生 } \\
\text { 産 }\end{array}$ & $\begin{array}{l}\text { 小農従事者数 : } 2 \text { 人 } \\
\text { (回答者と夫) }\end{array}$ & $\begin{array}{l}\text { 使用権のある水田で栽 } \\
\text { 培。 }\end{array}$ & 家屋敷地内 (庭) で栽培。 & 家屋敷地内 (庭)で栽培。 & $\begin{array}{l}\text { 使用権のない場所 } \\
\text { で飼育。 }\end{array}$ \\
\hline \multirow{2}{*}{$\begin{array}{c}\text { (4) } \\
45 \text { 歳女性 } \\
\text { (C 村 C } \\
\text { 集落 })\end{array}$} & $\begin{array}{l}\text { 消 } \\
\text { 費 }\end{array}$ & $\begin{array}{l}\text { 自家消費者数: } 3 \text { 人 } \\
\text { 八ノイ市の子供 }(2 \\
\text { 人), 都市部や近隣に } \\
\text { 住む親せきに農産物 } \\
\text { を供給 }\end{array}$ & $\begin{array}{l}2017 \text { 年から自家消費と } \\
\text { ハノイ市の子供のみで } \\
\text { 消費 (2016 年までは余 } \\
\text { 剰分を販売していた)。 }\end{array}$ & $\begin{array}{l}\text { 自家消費及び近隣親せ } \\
\text { きで消し, 仲買人が家 } \\
\text { に立ち寄ったときのみ } \\
\text { わずかながらも販売不 } \\
\text { 足分を購入。 }\end{array}$ & $\begin{array}{l}10 \% \text { 程度を自家消費, } \\
40 \% \text { 程度を親せき分 } \\
\text { け， } 50 \% \text { 程度を販売。 }\end{array}$ & $\begin{array}{l}\text { 鶏を自家消費 }\left(85^{-}\right. \\
90 \% \text { 程度）及び親せ } \\
\text { き（10-15\%）で消 } \\
\text { 費。 }\end{array}$ \\
\hline & 生 & $\begin{array}{l}\text { 小農従事者数：1 人 } \\
\text { (回答者) }\end{array}$ & $\begin{array}{l}\text { 使用権のある水田で栽 } \\
\text { 培。但し, } 2017 \text { 年から栽 } \\
\text { 培面積を前年比で } 3 / 5 \\
\text { に縮小し,販売を辞め自 } \\
\text { 家消費分にのみ栽培。 }\end{array}$ & $\begin{array}{l}\text { 家屋敷地周辺の空き地 } \\
\text { で } 50 \% \text { 程度分を栽培。 } \\
\text { 残り半分は使用権のな } \\
\text { い空き地で栽培。 }\end{array}$ & $\begin{array}{l}\text { バナナと柑橘果物を家 } \\
\text { 屋敷地内で栽培。 }\end{array}$ & $\begin{array}{l}\text { 家屋敷地内（庭）で } \\
\text { 飼育。 }\end{array}$ \\
\hline \multirow{2}{*}{$\begin{array}{c}\text { (5) } \\
39 \text { 歳女性 } \\
(\mathrm{C} \text { 村 } \mathrm{C} \\
\text { 集落 })\end{array}$} & $\begin{array}{l}\text { 消 } \\
\text { 費 }\end{array}$ & 自家消費者数: 7 人 & $\begin{array}{l}\text { 集落内の農家から消費 } \\
\text { 分すべて購入 }\end{array}$ & 自家消費のみ。 & $\begin{array}{l}\text { 柑橘果物を自家及びハ } \\
\text { ノイ市と集落内の親せ } \\
\text { きで消費。余利を販売。 }\end{array}$ & $\begin{array}{l}\text { 鶏を自家消費用に } \\
\text { 飼育。 }\end{array}$ \\
\hline & $\begin{array}{l}\text { 生 } \\
\text { 産 }\end{array}$ & $\begin{array}{l}\text { 小農従事者数 : } 1 \text { 人 } \\
\text { (回答者) }\end{array}$ & なし & 家屋敷地内 (庭) で栽培。 & 家屋敷地内 (庭)で栽培。 & $\begin{array}{l}\text { 家屋敷地内（庭）で } \\
\text { 飼育。 }\end{array}$ \\
\hline
\end{tabular}


る主体について「農業経営体」と総称することとする。

注 2）日本の小農学会共同代表の山下惣一によると,「主に家族 労㗢によって暮らしを目的として営まれているのが『小農』 であり，規模は小さくても雇用主体で利潤追求を目的とす るのは『大農』である。」 ${ }^{5)}$ 本論では, 目的について山下の 考え方を共有しつつ,「農業経営体」については雇用労働・ 家族労働の別を問わず利益追求を目的として農を営む主体 を指すものとする。

注 3） GSO (2007) ${ }^{10)}$ に基づく旧ハタイ省の面積/世帯を参照。

注 4）調查 4.の調查票調查は, 自記式集合法にて実施した。標 本数は, $\mathrm{a} 1 ： n=100, \mathrm{~b} 2: n=100, \mathrm{c}: n=66$ 。調查 5 . は, 筆 者作成の質問票に基づき，各集落の協力者がそれぞれの集 落内でチャンチャイと認識されている農場に聞きとりを行 ったもの。回答数は, $\mathrm{a} 1: n=19, \mathrm{a} 2: n=13, \mathrm{~b} 1: n=11, \mathrm{~b} 2: n=4$, c: $n=3$.

注 5）調査票では, 現地調查協力者と相談の上, 小さな農とし ての「Làm ruộng（直訳「農業」, 本論では「(1)農的生産活 動（小農）」，儲かる大きな農業としての「Trang trại（直 訳「チャンチャイ/大規模私営農場」, 本論では「(2)農場経 営（農業経営体）」）をそれぞれに採用した。

注 6）対象地のチャンチャイと呼ばれる農場経営体は, 1993 年 土地法改正時に平等に配分された水田使用権とは別に, 居 住地から離れた場所で畜産等の施設を含むVAC モデルが設 置される土地が必要とされる。調查 5. では, 2013 年に実施 された農地再配分の手続きの際に意思決定に関わった各集 落のリーダー (1 名/集落 $\times 5$ 集落 $)$ に対しても調查票を配 布し, チャンチャイと呼ばれる主体の特徵を聴取した。

\section{引用文献}

1）岩元泉（2013）：現代農業における家族経営の論理. 農業経 営研究，50(4)，9-19.

2）農林水産省 (2016)：第 2 巻農林業経営体調査報告書一総括 編一, 2015 年農林業センサス.
3）秋津元輝（2014）：食と農をつなぐ倫理を問い直す（桝潟俊 子・谷口吉光・立川雅司編, 『食と農の社会学』）.ミネルヴァ 書房, 京都, 275-292.

4) HLPE (2013): Investing in smallholder agriculture for food security. A report by the High Level Panel of Experts on Food Security and Nutrition of the Committee on World Food Security, Rome.

5）山下惣一 (2016) : 神の神髄は小農にあり, 現代農業, 2016. 4., 344-347.

6) Rigg, J., Salamanca, A., \& Thompson, E. C. (2016): The puzzle of East and Southeast Asia's persistent smallholder. Journal of Rural Studies, 43, 118-133.

7) GSO(General Statistics Office) (2007): Results of the 2006 Rural, Agricultural and Fishery Census. Statistical Publishing House, Hanoi.

8) Ploeg, Douwe van der, J. (2010): The peasantries of the twenty-first century: the commoditisation debate revisited. The Journal of Peasant Studies, 37(1), 1-30.

9) 桜井由躬雄 (1987)：『ベトナム村落の形成：村落共有田. 創 文社』.東京.

10）荒神衣美（2010）：大規模私営農場の成長と農業近代化. アジ研ワールド・トレンド。 177 号 (6月)，8-11.

11) Inoue, K., Nguyen, T. N., Pham, T.D., and Yamaji, E. (2016): The Reality of Rural Communities Revealed in a Rural Development Project: A Comparative Study on Three Rural Communities in the Red River Delta, Vietnam, Journal of rural planning, 35 (Special Issue), 266-273.

12) Blad, M. (2010): Pluriactivity of farming families: old phenomenon in new times. European Rural Development Network Studies, 7, 155-165.

13）松木洋一 (2003) : ヨーロッパの家族農業経営の多様就業活 動 Pluriactivity と企業形態の転換（金沢夏樹 編，『家族農 業経営の底力』, 農林統計協会, 154-177.

Summary : This study is to examine possibility of alternative course of rural development by demonstrating and analyzing field survey results in the rural area of the Red River Delta, Vietnam, with special attention to the bipolarizing trend of farming management entity. The study showed data to capture farmers' pluriactivity in the individual, household, and community levels of five target villages, indicating that 1) profit-seeking farming bodies have emerged recently with significantly larger level of income in comparison with smallholder agriculture, and 2) majority of rural smallholders continue farming even with available non-farming business opportunities. By showing robust existence of smallholders in Vietnam, the paper suggests possibility of alternative rural development in the light of self-provisioning features of smallholder agriculture together with long-lasting community tie to share non-farming job opportunities each other, which enable smallholders to ensure their livelihood and quality-food to be supplied by themselves, reducing dependency on external resources.

キーワード (Keywords）：小農（Smallholder Agriculture），多様就業（Pluriactivity），ベトナム（Vietnam）, 食と農（Food and Agriculture) 